\title{
PERANCANGAN SISTEM KEPEGAWAIAN (HUMAN RESOURCE MANAGEMENT) BERBASIS WEB MENGGUNAKAN FRAMEWORK CODEIGNITER DI RUMAH SAKIT ADVENT BANDAR LAMPUNG
}

\author{
Joseph Fristson Hamonangan, \\ Rumah Sakit Advent Bandar Lampung, Kota Bandar Lampung, Lampung \\ e-mail: jsph.hamonangan@gmail.com
}

\begin{abstract}
Abstrak
Rumah Sakit Advent Bandar Lampung (RSABL) adalah institusi perawatan kesehatan profesional yang memiliki sistem manajemen sumber daya (human resources management) yang menggunakan media pengolahan data Ms. Excel. (Human Resource Department) HRD akan mengolah data setiap karyawan yang ada menggunakan media (software) pengolahan data untuk membuat dokumentasi mengenai absensi hingga analisa gaji berdasarkan absensi yang sudah dikelola. Inovasi pemrograman dan database sebagai media kapasitas dapat bermanfaat dalam membuat perbedaan klasifikasi informasi data. Perbaikan dari Framework yang digunakan dalam penelitian ini adalah waterfall. Strategi ini terdiri dari pengumpulan prasyarat, pemeriksaan, rencana kerangka kerja, eksekusi, pengujian, dan dukungan. Framework ini direncanakan menggunakan Framework Codeigniter. Hasil uji coba sistem Human Resource Management dapat mengelola data karyawan, mengelola data absen, melakukan pengajuan cuti dan data gaji pada RSABL dengan baik.
\end{abstract} Codeigniter

Kata Kunci: Human Resource Management(HRM), Human Resource Department(HRD), Website,

\section{DESIGN OF A WEB-BASED EMPLOYMENT SYSTEM (HUMAN RESOURCES) WITH CODEIGNITER FRAMEWORK AT ADVENT HOSPITAL BANDAR LAMPUNG}

\begin{abstract}
Bandar Lampung Adventist Hospital (RSABL) is a professional health care institution that has a human resources management system that uses MS. Excel. (Human Resource Department) HRD will process data for each existing employee using data processing media (software) to create documentation regarding attendance to salary analysis based on managed attendance. Programming technology and databases as storage media can be useful in helping classify information data. The development of the system used in this research is the waterfall. This method consists of requirements gathering, analysis, system design, implementation, testing, and maintenance. This system is designed using the Codeigniter framework. The results of the trial of the Human Resource Management system can manage employee data, manage absent data, submit leave requests and salary data at RSABL properly.
\end{abstract}

Keywords: Human Resource Management (HRM), Human Resource Department (HRD), Website, Codeigniter 


\section{Pendahuluan}

Human Resources Management adalah salah satu hal penting bagi perusahaan dalam mengawasi tujuan [1]. Penggunaan teknologi merupakan salah satu komponen penting untuk mengawasi proses bisnis dalam administrasi perusahaan. Klinik Advent Bandar Lampung (RSABL) adalah institusi perawatan kesehatan profesional yang memiliki sistem manajemen sumber daya (human resources management). HRM adalah salah satu variabel penting terpenting untuk kemenangan perdagangan [1]. Dalam HRM memiliki sistem informasi khusus dalam area fungsional tradisional organisasi, yang dirancang untuk mendukung perencanaan, administrasi, pengambilan keputusan dan aktivitas pengendalian sumber daya manusia [2]. Dalam hal ini, kerangka administrasi aset HRD dapat menyiapkan informasi yang representatif dengan mempertimbangkan aset yang ada dapat diawasi dengan lebih layak dan efisien.

Sistem manajemen sumber daya yang dilakukan pada RSABL menggunakan media pengolahan data seperti Ms. Excel. (Human Resource Department) HRD akan mengolah data setiap karyawan yang ada menggunakan media (software) pengolahan data untuk membuat dokumentasi mengenai absensi hingga analisa gaji berdasarkan absensi yang sudah dikelola. Teknis pengolahan absensi tersebut tidak terintegrasi secara langsung karena sistem absensi yang mengharuskan HRD mengolah langsung dan menganalisa satu per satu dari setiap karyawan yang ada. Adapun pengolahan data lain selain data absensi dan data gaji adalah komunikasi. Dengan adanya fitur komunikasi ini HRD dan karyawan lainnya tidak dapat saling bertemu komunikasi yang dilakukan menggunakan media pesan yang bersifat umum. Dari beberapa sistem olah data hingga komunikasi tersebut tentu tidak efektif dimana sistem bersifat tidak terpusat. Sistem yang tidak terpusat di RSABL membutuhkan pengembangan supaya integrasi data absensi dapat melakukan analisa dengan cepat hingga menghasilkan kesimpulan berupa detail gaji karyawan. Adapun media komunikasi dapat dilakukan pada sistem yang telah terintegrasi berbasis Website demi memudahkan pemusatan khusus di lingkungan RSABL.

Berdasarkan permasalahan diatas maka penulis akan melakukan penelitian dengan judul "Perancangan Sistem Kepegawaian (Human Resource Management) berbasis web dengan Framework Codeingniter pada Rumah Sakit Advent Bandar Lampung" untuk mengoptimalkan pengolahan data karyawan dan komunikasi yang terpusat.

\section{Metode Penelitian}

Metode penelitian yang digunakan penulis adalah sistem pengembangan SDLC dengan tahap-tahap sebagai berikut:

1. Analisa Kebutuhan

Penulis melakukan analisa terhadap permasalahan yang terjadi pada sistem kepegawaian di RSABL dengan melibatkan petugas secara langsung supaya mendapatkan solusi yang dibutuhkan.

2. Desain Sistem

Tahap desain ini dilakukan untuk membuat perancangan sistem yang akan dibangun menggunakan Unified Modelling Language (UML) dan tatap muka (Balsamiq).

3. Implementasi

Tahap implementasi akan dilakukan eksekusi desain menggunakan program untuk menghasilkan sistem yang dibutuhkan.

4. Pengujian

Sistem yang telah dibangun akan diuji menggunakan metode Blackbox Testing apakah sesuai dengan kebutuhan di tahap ini.

\section{Human Resource Management}

Manajemen sumber daya manusia (Human Resource Management) adalah salah satu bidang administrasi umum yang menggabungkan sudut pengaturan, pengorganisasian, pelaksanaan dan 
pengendalian. Aset manusia dianggap memiliki peran yang semakin penting dalam mencapai tujuan, sehingga berbagai pertemuan dan pertanyaan yang terjadi di bidang aset manusia dikumpulkan secara efisien dalam apa yang disebut manajemen aset manusia. eksekusi yang cukup dan jangan mengontrak perwakilan yang tidak berguna [3].

\section{Sistem Manajemen}

Sistem Manajemen adalah standar yang memuat prasyarat untuk membantu perusahaan atau organisasi menjadi lebih sukses dan produktif serta meningkatkan kepuasan klien. Dalam penggunaan kerangka kerja administrasi koordinat, pemimpin memiliki bagian yang sangat penting dalam menjalankan kerangka kerja dan mencirikan otoritas sebagai metode untuk mempengaruhi orang lain untuk memahami dan setuju dengan apa yang harus mereka lakukan dan bagaimana melakukan tugas ini dengan baik, serta metode mendorong orang dan sekelompok upaya untuk mewujudkan tujuan. (shared goal) [4].

\section{Website}

Website adalah halaman web lengkap yang terdapat dalam domain yang berisi data. Sebuah situs online biasanya dibangun di atas banyak halaman web yang saling berhubungan. Hubungan antara satu halaman web dengan halaman web lainnya disebut hyperlink, sedangkan konten yang digunakan sebagai media penghubung disebut hypert. Untuk membangun sebuah halaman web dibutuhkan dialek pemrograman yang lebih dikenal dengan web scripting. Dikatakan skrip karena perintah kode program akan diterjemahkan dan tidak ada kompilasi untuk membuatnya dapat dieksekusi. Berdasarkan area penanganan mediator, web scripting dibedakan menjadi dua kategori, yaitu client side dan server side. Sisi klien dilakukan oleh browser web seperti Web Pilgrim, Netscape, Drama musikal, dan Firefox. Contoh dari bahasa client side adalah HTML, CSS, Javascript, VBscript, dan XML. Sedangkan sisi server dilakukan oleh web server seperti PWS (Individual Web Server for Windows 98 Working Framework), IIS (untuk Windows 2000/Windows XP Working Framework), Apache, Tomcat, Xitami, dan ZOPE. Untuk kasus dialek sisi server adalah ASP (.Net), PHP, JSP, CFM, dan CGI/PL [5].

\section{Codeigniter}

Codeigniter adalah sebuah Framework PHP yang dapat membantu mempercepat developer dalam pengembangan aplikasi web berbasis PHP dibandingkan jika menulis semua kode program dari awal. Codeigniter menyediakan banyak library untuk mengerjakan tugas-tugas yang umumnya ada pada sebuah aplikasi berbasis web. Selain itu, struktur dan susunan logis dari Codeigniter membuat aplikasi yang dibuat menjadi semakin teratur dan rapi. Dengan demikian, dapat fokus pada fitur-fitur apa yang dibutuhkan aplikasi dengan membuat kode program seminimal mungkin. Alasan penggunaan Codeigniter Framework merupakan PHP Framework open source untuk pengembang web yang mendukung pola MVC. Objek utama dari Framework ini untuk menghadirkan cara yang simpel dan efisien untuk menyelesaikan proyek pengembangan web. Menjadikan proyek pengembangan web lebih mudah dan cepat [6].

Ada beberapa kelebihan Codeigniter (CI) dibandingkan dengan Framework PHP lain. Salah satu kelebihan Codeigniter (CI) yaitu berukuran kecil, ukuran Codeigniter yang kecil merupakan keunggulan tersendiri. Dibanding Framework lainnya yang berukuran besar, serta membutuhkan resource yang besar pula untuk berjalan. Pada Codeigniter, bisa diatur agar sistem me-load library yang dibutuhkan saja, sehingga dapat berjalan ringan dan cepat [6].

\section{Penelitian Terdahulu}

Penelitian terdahulu yang dilakukan John dan Husein. Penelitian ini menyimpulkan bahwa sistem HRIS yang dibangun dapat membantu dalam pengolahan data kepegawaian yang berada di PT. Tata Raya Steel 
[7]. Penelitian terdahulu yang dilakukan Luthfi dan Minarni menghasilkan Sistem informasi Human Resource yang dapat mempermudah pihak perusahaan untuk mengelola data bagian kepegawaian dengan pengelolaan data personal karyawan yang semua sudah terintegrasi baik dari awal permintaan tenaga kerja yang dapat diketahui dengan mudah [8]. Penelitian terdahulu yang dilakukan Junaedi. Penelitian ini menghasilkan Aplikasi HRIS yang bisa membantu perusahaan dalam mengolah data dengan baik . sistem ini memiliki hak akses untuk merubah dan melihat data pegawai tersebut [9].

\section{Hasil dan Pembahasan}

Sistem dirancang sesuai dengan analisa kebutuhan untuk menjadi solusi dari permasalahan yang ada. Berikut adalah perancangan yang digunakan dalam penelitian ini.

\section{Use case Diagram}

Use case diagram dibuat untuk menjelaskan jumlah aktor dan hak akses dari setiap aktornya adalah seperti Gambar 1.

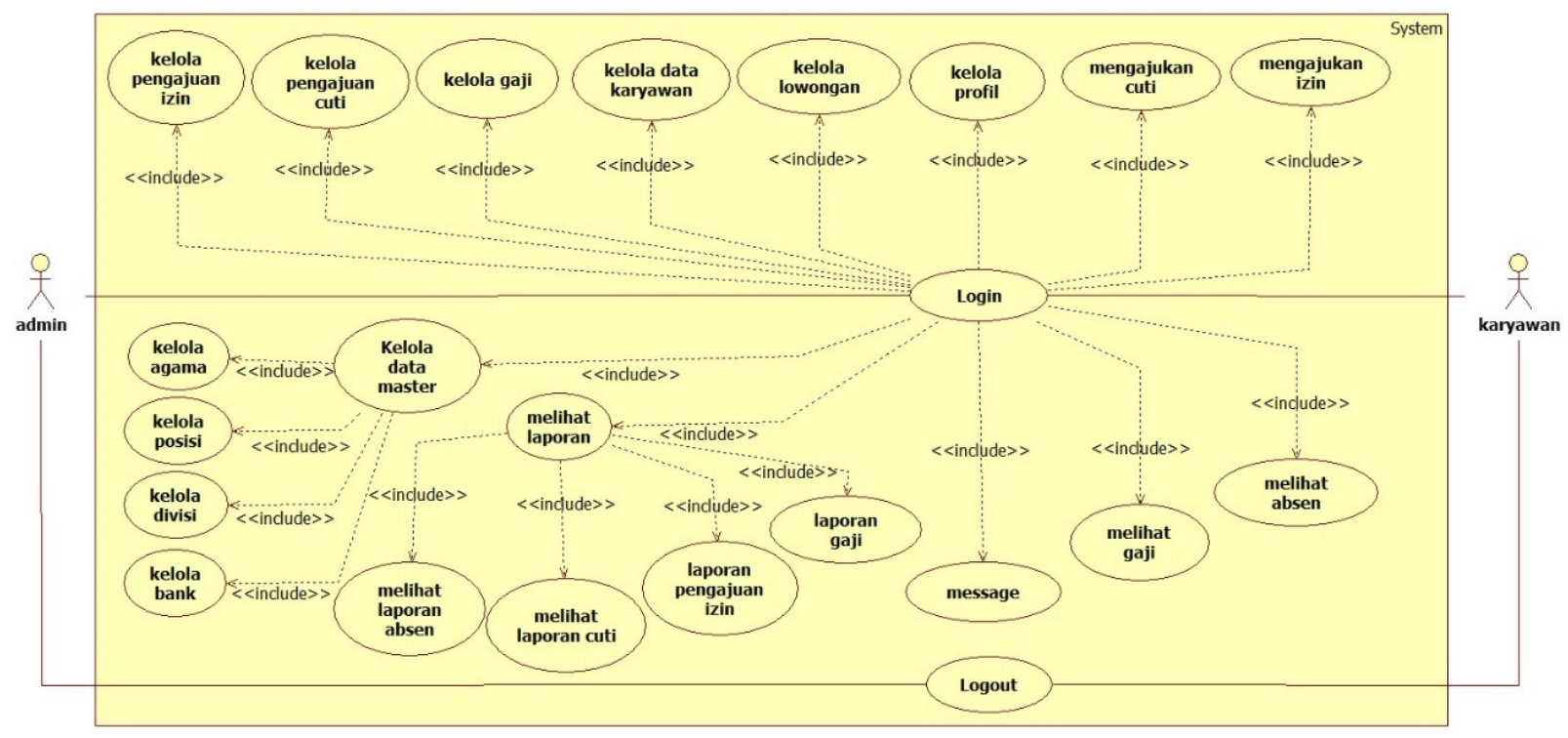

Gambar 1 Use case Diagram

\section{Activity Diagram}

Activity diagram dirancang untuk menjelaskan aktifitas yang terjadi dari setiap akses pada masingmasing aktor seperti berikut :

1. Login

Pada activity diagram ini menggambarkan alur ketika melakukan login, ketika login jika karyawan terjadi kesalahan input maka akan kembali pada menu memasukkan username karyawan seperti Gambar 2. 


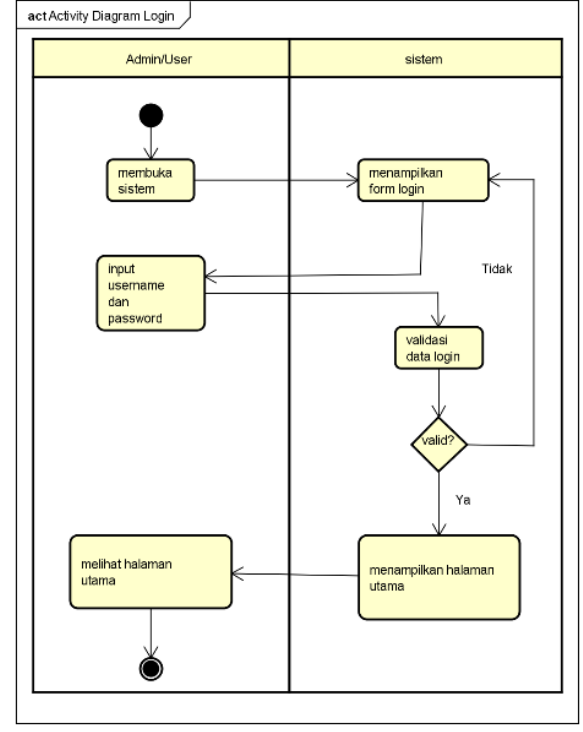

Gambar 2 Activity diagram Login

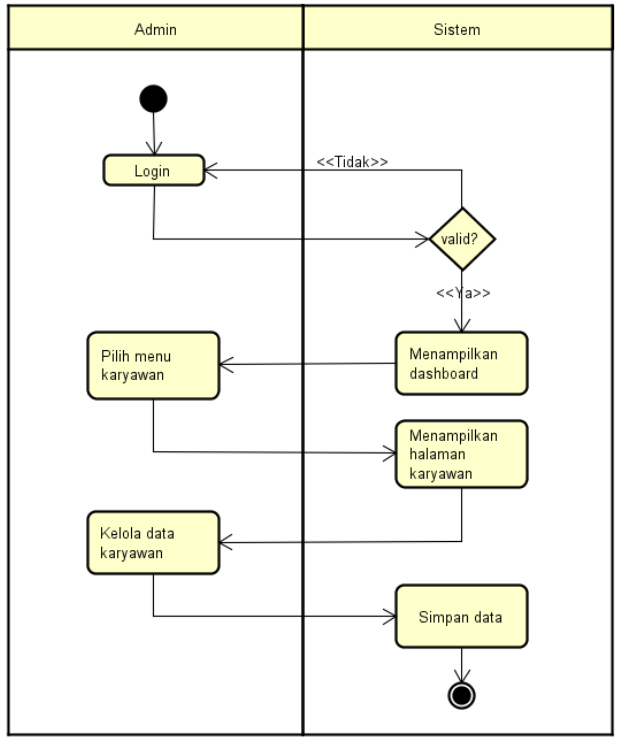

Gambar 3 Activity diagram Karyawan

2. Kelola data karyawan

Pada activity diagram ini menggambarkan admin dalam mengelola data karyawan seperti menambah data baru, edit dan hapus data karyawan seperti Gambar 3.

3. Kelola Lowongan

Pada activity diagram ini menjelaskan admin dalam mengelola data lowongan, seperti menambah data, ubah dan hapus data lowongan seperti Gambar 4.

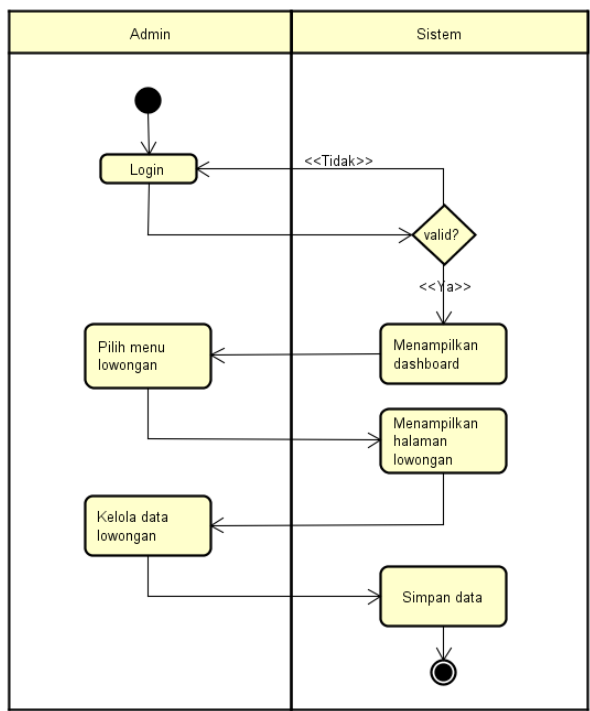

Gambar 4 Activity diagram Lowongan

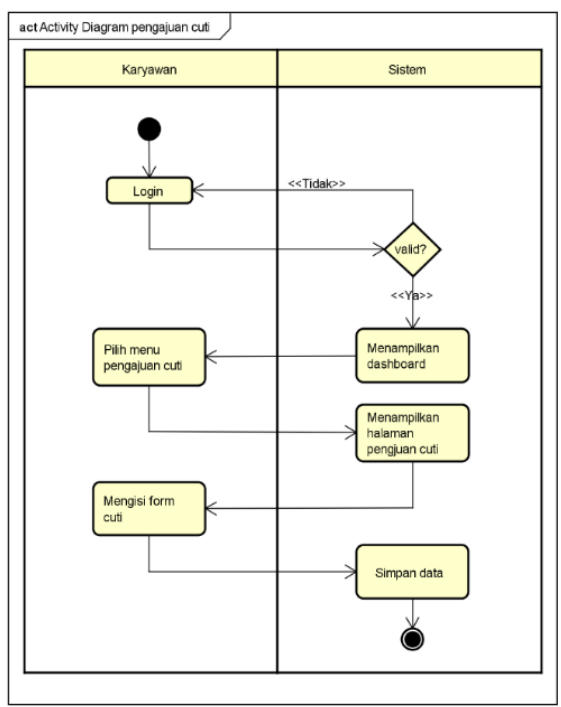

Gambar 5 Activity diagram Melihat Pengajuan Cuti

4. Kelola Pengajuan Cuti

Pada activity diagram ini menggambarkan admin dapat melihat pengajuan cuti, admin juga dapat meng-approve atau menolak pengajuan cuti dari karyawan seperti Gambar 5. 
5. Kelola Gaji

Pada activity diagram ini menggambarkan admin dapat melakukan penggajian dengan mengisi form gaji seperti Gambar 6.

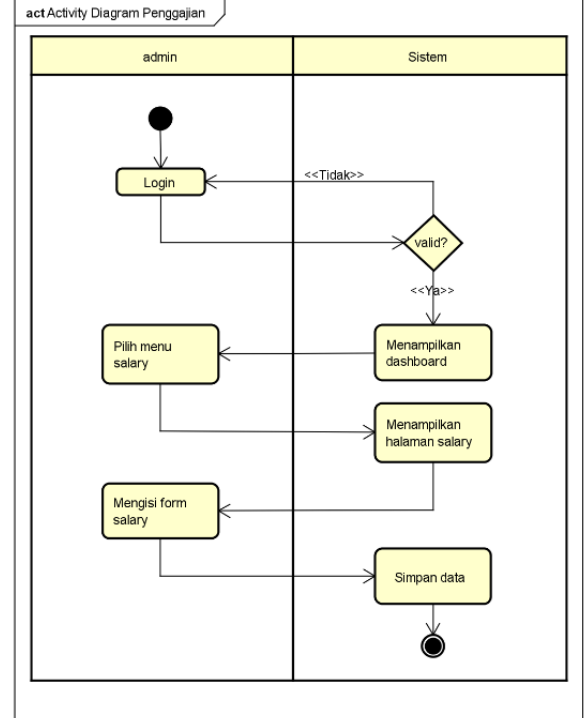

Gambar 6 Activity diagram Kelola Gaji

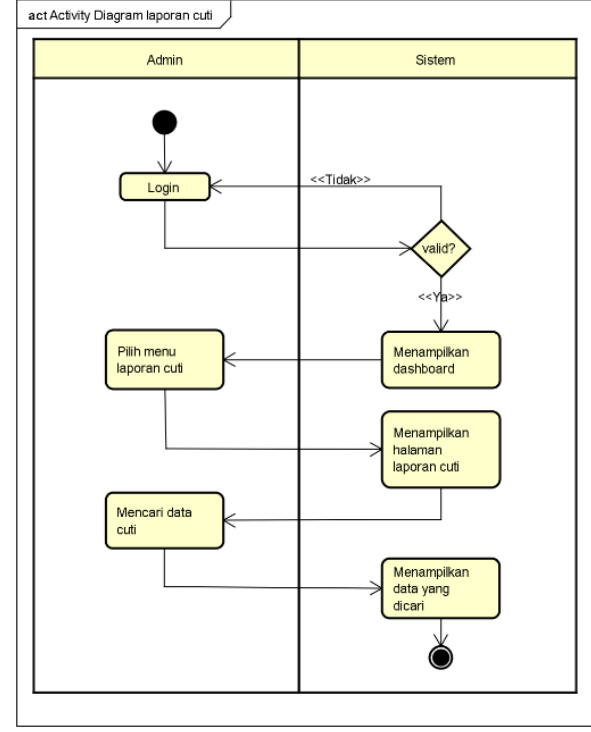

Gambar 7 Activity diagram Laporan Cuti

6. Melihat Laporan Cuti

Pada activity diagram ini menggambarkan admin dalam melihat laporan cuti atau (permit application), dan menampilkan data cuti dari periode tertentu seperti Gambar 7.

7. Melihat Laporan Gaji

Pada activity diagram ini menggambarkan admin dalam melihat laporan penggajian, dan menampilkan dari gaji dari periode tertentu seperti Gambar 8.

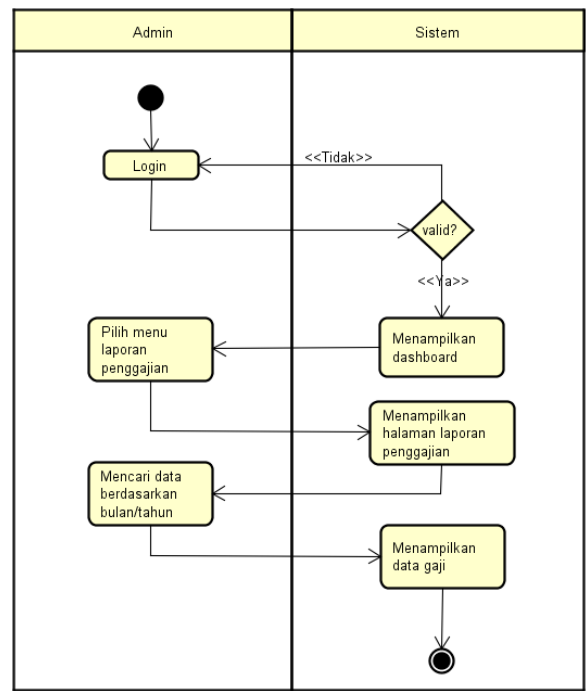

Gambar 8 Activity diagram Laporan Penggajian

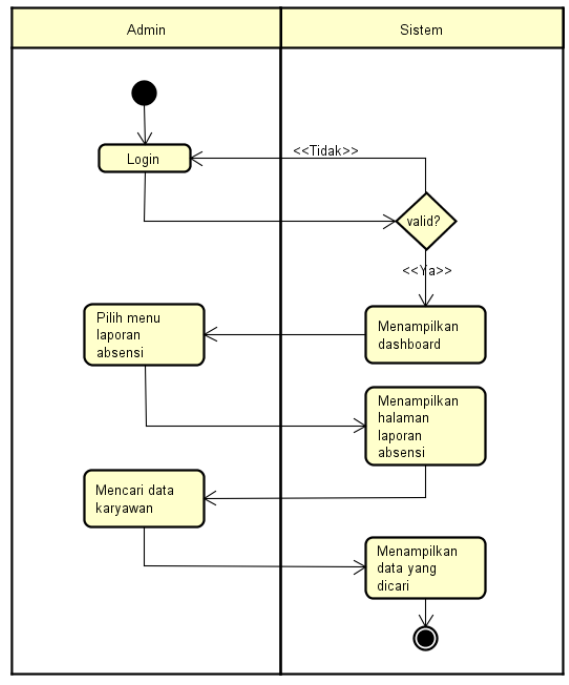

Gambar 9 Activity diagram Laporan Absensi 
8. Melihat Laporan Absen

Pada activity diagram ini menggambarkan admin dalam melihat data laporan absensi karyawan seperti Gambar 9.

\section{Class Diagram}

Class diagram dirancang untuk menggambarkan struktur kelas data pada sistem yang akan dibangun seperti berikut.

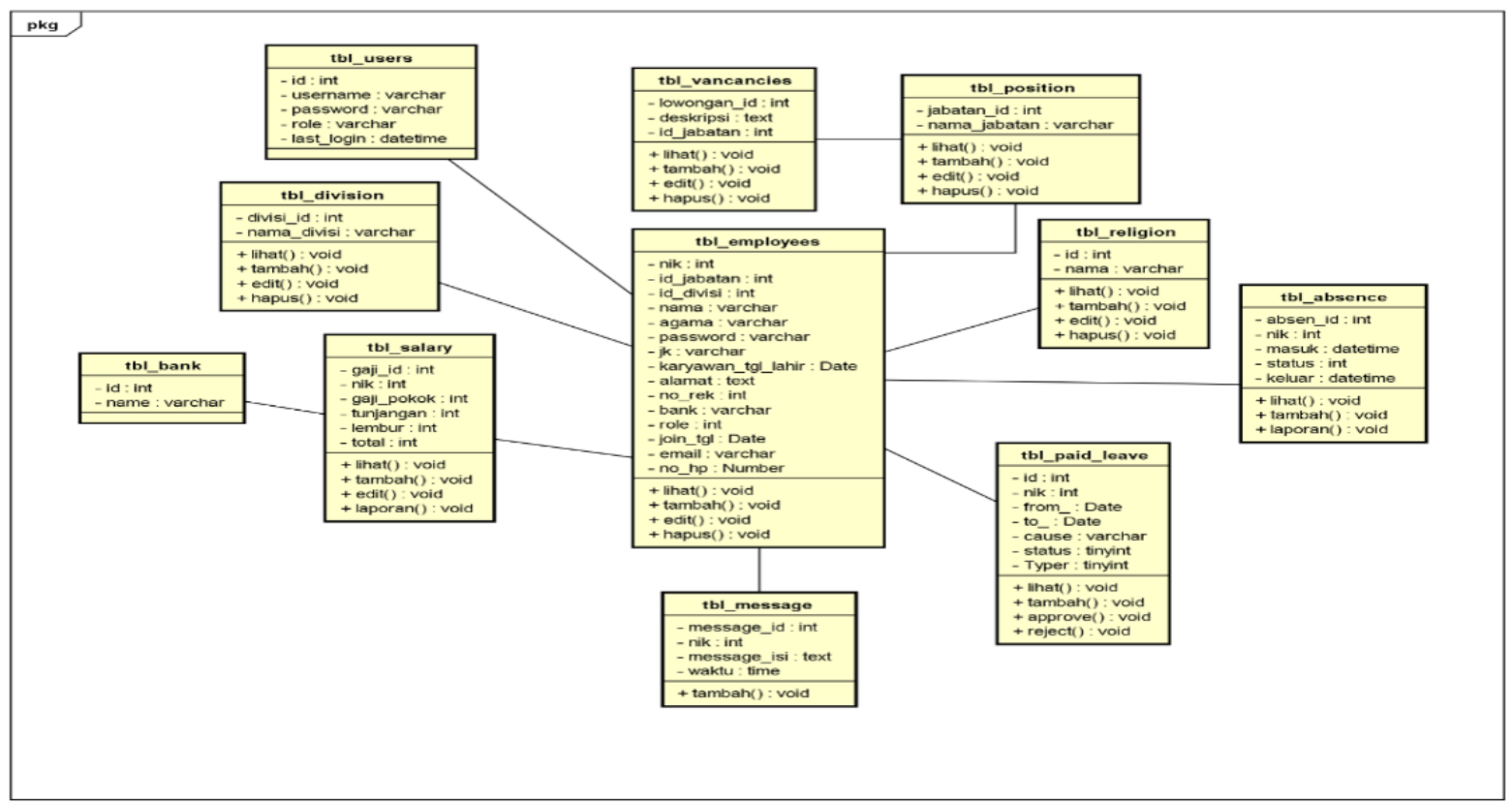

Gambar 10 Class Diagram

\section{Tampilan User Interface}

Berikut adalah beberapa perancangan tampilan dari aplikasi yang sudah terimplementasi, namun peneliti juga menyediakan versi Video dari demo aplikasi yang dapat diakses di: https://youtu.be/xP7QvxQ8Xc0

1. Halaman Login

Halaman login adalah halaman utama ketika sistem dijalankan dimana pengguna harus memasukkan data pengguna untuk dapat mengakses sistem seperti Gambar 11.

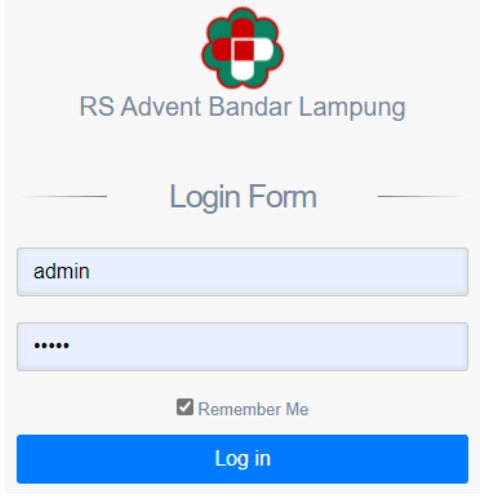

Gambar 11 Halaman Login 


\section{Halaman Dashboard Admin}

Dashboard adalah halaman utama yang disuguhkan ketika admin berhasil mengakses sistem seperti Gambar 12.
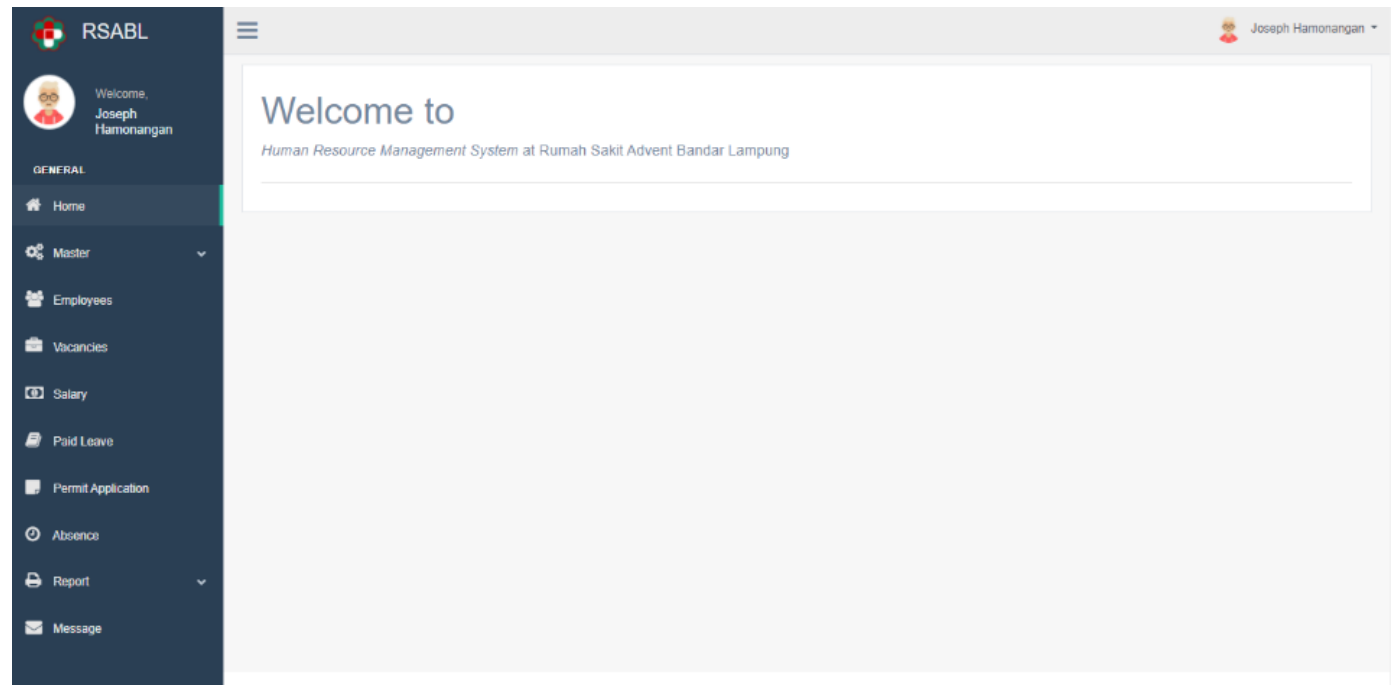

Gambar 12 Halaman Dashboard Admin

3. Halaman Employee Admin

Halaman employee adalah halaman admin dalam kelola data employee yang ada. Pada halaman employee admin dapat melihat data employee, menambah data employee, mengedit data employee, dan menghapus data employee sistem seperti Gambar 13.

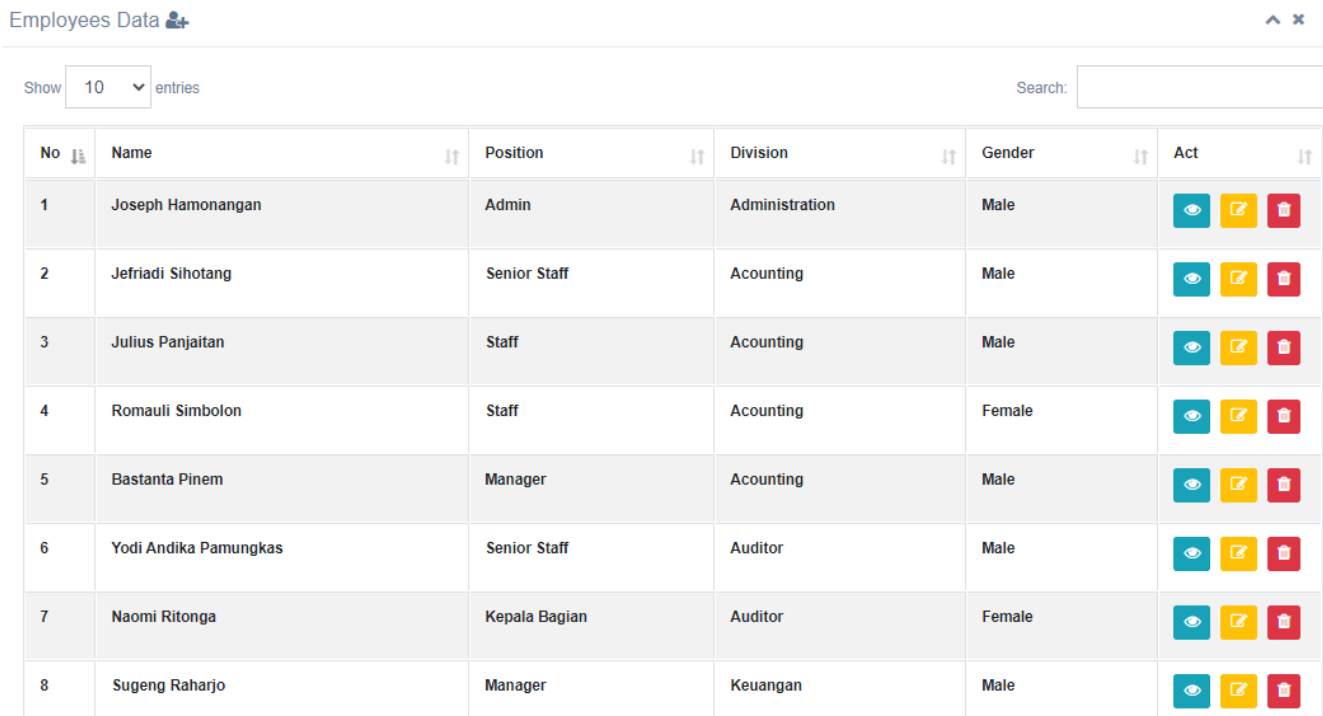

Gambar 13 Halaman Employee Admin

4. Halaman Dashboard Karyawan

Dashboard adalah halaman utama yang disuguhkan ketika karyawan berhasil mengakses sistem sistem seperti Gambar 14. 


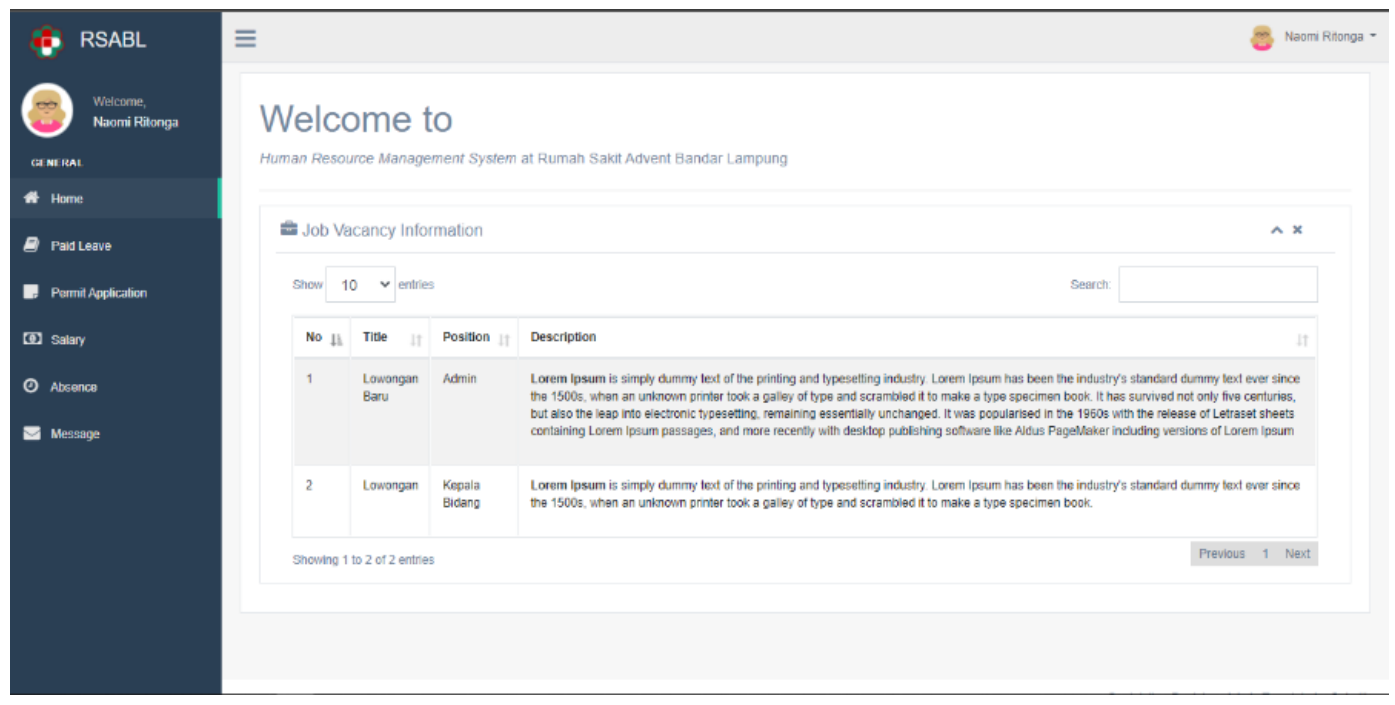

Gambar 14 Halaman Dashboard Karyawan

5. Halaman Laporan Absen Karyawan

Halaman laporan absensi merupakan halaman yang menampilkan laporan absensi kepada karyawan seperti Gambar 15.

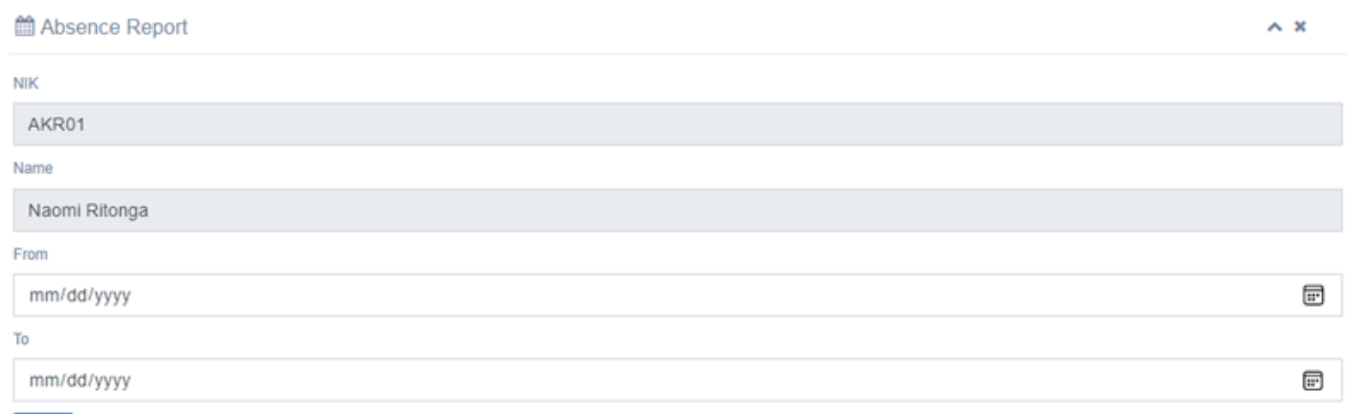

Show

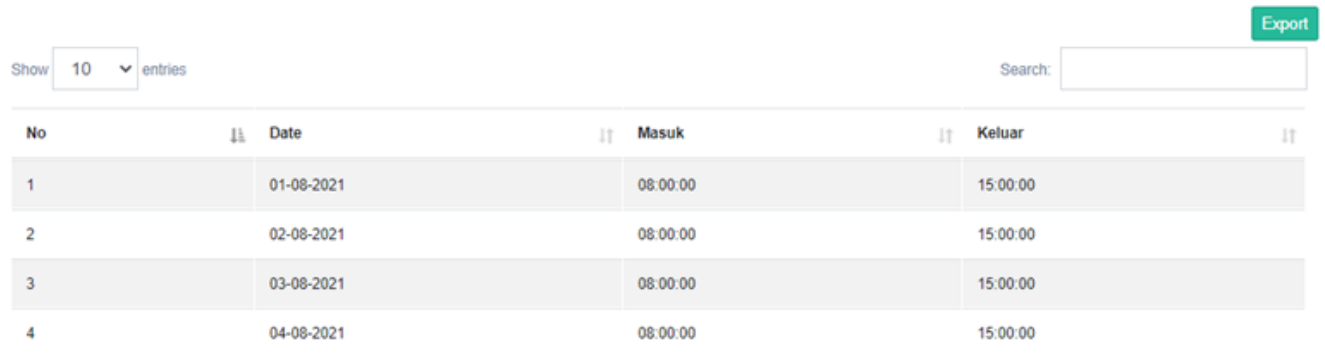

Gambar 15 Halaman Laporan Absen Karyawan

6. Halaman Messages Karyawan

Halaman message adalah halaman karyawan dalam melakukan interaksi melalui pesan teks. Berikut ini hasil implementasi halaman messages karyawan seperti Gambar 16. 

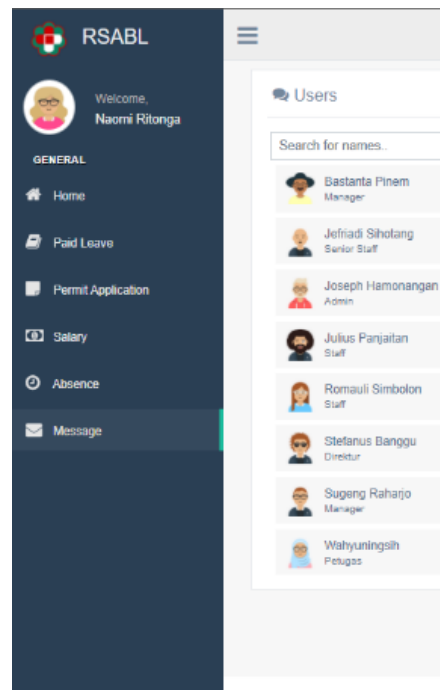

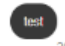
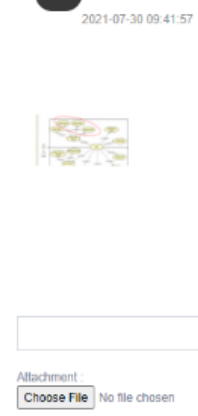

Gambar 16 Halaman Messages Karyawan

7. Halaman Profil Karyawan

Halaman profil adalah halaman dimana karyawan dapat perbarui data profil. Berikut ini hasil implementasi halaman profil karyawan seperti Gambar 17.

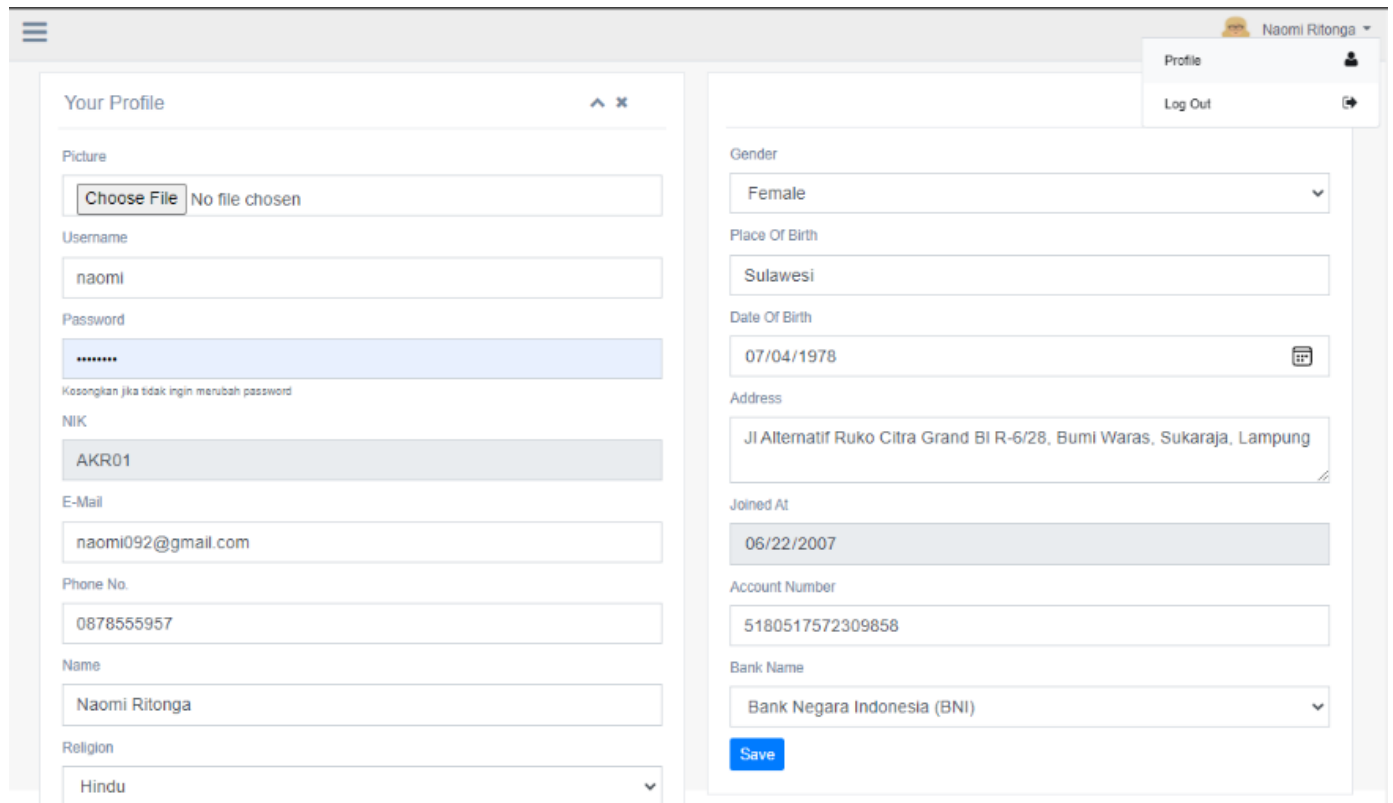

Gambar 17 Halaman Profil Karyawan

8. Halaman Paid Leave

Halaman paid leave ialah halaman yang menampilkan data pengajuan cuti atau permohonan izin oleh karyawan yang masih digaji oleh perusahaan. Pada halaman ini juga terdapat form input pengajuan seperti Gambar 18. 


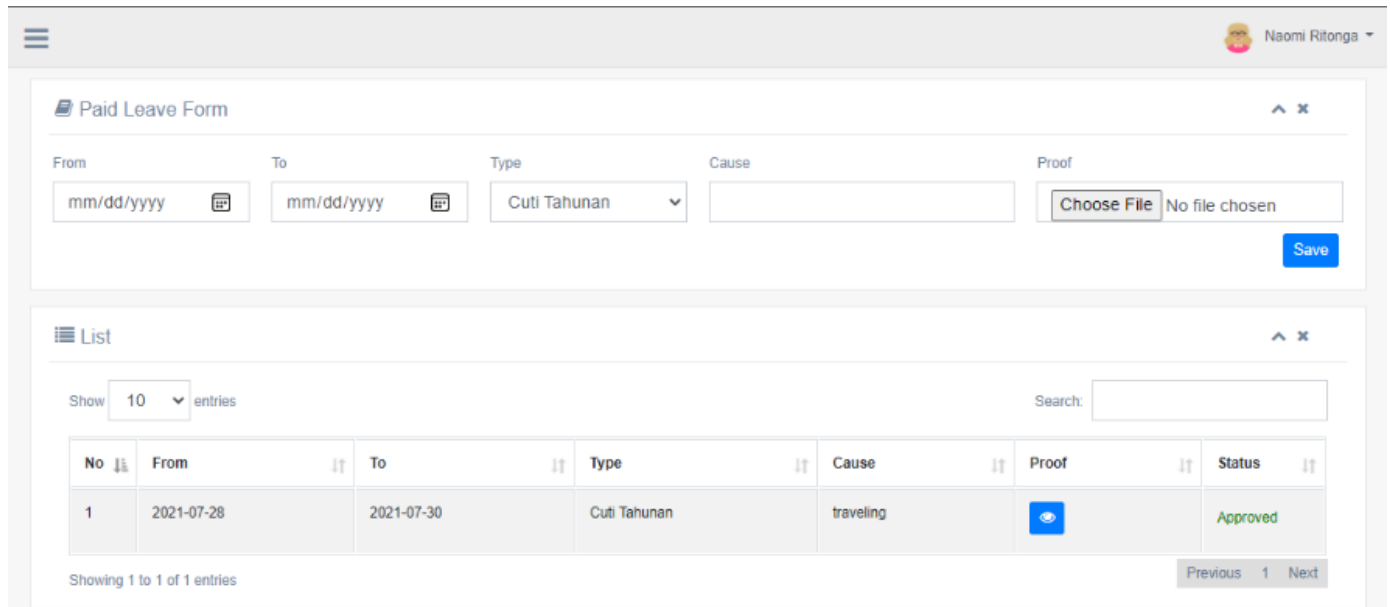

Gambar 18 Halaman Pengajuan Cuti Karyawan

\section{Hasil Pengujian}

Metode pengujian yang dilakukan untuk uji coba sistem ini adalah black-box testing [10]. Berikut adalah hasil pengujian sistem yang telah dilakukan.

Tabel 1 Hasil Pengujian Admin

\begin{tabular}{|c|c|c|c|}
\hline No. & Komponen Sistem Yang Diuji & Butir Uji & Jenis Pengujian \\
\hline 1 & Login & Login & $\begin{array}{c}\text { [ } \sqrt{ }] \text { Diterima } \\
\text { [ ] Ditolak }\end{array}$ \\
\hline \multirow{3}{*}{2} & \multirow{3}{*}{ Kelola Divisi } & menambah data & \multirow{3}{*}{$\begin{array}{c}{[\sqrt{ }] \text { Diterima }} \\
{[\text { ] Ditolak }}\end{array}$} \\
\hline & & mengubah data & \\
\hline & & menghapus data & \\
\hline \multirow{3}{*}{3} & \multirow{3}{*}{ Kelola Agama } & menambah data & \multirow{3}{*}{$\begin{array}{c}{[\sqrt{ }] \text { Diterima }} \\
\text { [ ] Ditolak }\end{array}$} \\
\hline & & mengubah data & \\
\hline & & menghapus data & \\
\hline \multirow{3}{*}{4} & \multirow{3}{*}{ Kelola Bank } & menambah data & \multirow{3}{*}{$\begin{array}{c}{[\sqrt{ }] \text { Diterima }} \\
{[\text { ] Ditolak }}\end{array}$} \\
\hline & & mengubah data & \\
\hline & & menghapus data & \\
\hline \multirow{3}{*}{5} & \multirow{3}{*}{ Kelola Jabatan } & menambah data & \multirow{3}{*}{ 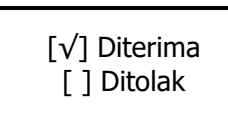 } \\
\hline & & mengubah data & \\
\hline & & menghapus data & \\
\hline \multirow{3}{*}{6} & \multirow{3}{*}{ Kelola Karyawan } & menambah data & \multirow{3}{*}{$\begin{array}{c}{[\sqrt{ }] \text { Diterima }} \\
\text { [ ] Ditolak }\end{array}$} \\
\hline & & mengubah data & \\
\hline & & menghapus data & \\
\hline \multirow{3}{*}{7} & \multirow{3}{*}{ Kelola Lowongan } & menambah data & \multirow{3}{*}{ 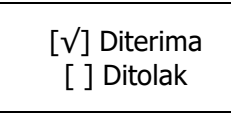 } \\
\hline & & mengubah data & \\
\hline & & menghapus data & \\
\hline 8 & Laporan Absen & Lihat laporan data absensi & $\begin{array}{c}\text { [V] Diterima } \\
\text { [ ] Ditolak }\end{array}$ \\
\hline 9 & Laporan Penggajian & Lihat laporan data penggajian & $\begin{array}{l}\text { [V] Diterima } \\
\text { [ ] Ditolak }\end{array}$ \\
\hline 10 & Messages & Mengirim pesan & 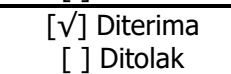 \\
\hline \multirow{3}{*}{11} & \multirow{3}{*}{ Pengajuan Cuti } & Approve pengajuan & $\begin{array}{l}\text { [V] Diterima } \\
\text { [ ] Ditolak }\end{array}$ \\
\hline & & Reject pengajuan & $\begin{array}{l}{[\sqrt{ }] \text { Diterima }} \\
\text { [] Ditolak }\end{array}$ \\
\hline & & Hapus pengajuan & $\begin{array}{l}\text { [V] Diterima } \\
\text { [ ] Ditolak }\end{array}$ \\
\hline 12 & Permit Application & Approve pengajuan & $\begin{array}{c}{[\sqrt{ }] \text { Diterima }} \\
\text { [ ] Ditolak }\end{array}$ \\
\hline
\end{tabular}




\begin{tabular}{|c|c|c|}
\multirow{n}{*}{} & Reject pengajuan & $\begin{array}{c}{[\sqrt{ }] \text { Diterima }} \\
{[] \text { Ditolak }}\end{array}$ \\
\cline { 2 - 3 } & Hapus pengajuan & $\begin{array}{c}{[\sqrt{ }] \text { Diterima }} \\
{[] \text { Ditolak }}\end{array}$ \\
\hline
\end{tabular}

\section{Kesimpulan}

Berdasarkan dari bab-bab sebelumnya, maka dapat disimpulkan sebagai berikut:

1. Berdasarkan hasil uji coba sistem Human Resource Management dapat mengelola data karyawan, mengelola data absen, dan data gaji pada RSABL dengan baik.

2. Peneliti berhasil membangun fasilitas media komunikasi (chat) yang terpusat pada sistem khusus lingkungan RSABL, sehingga dapat memudahkan komunikasi antar karyawan yang ada di lingkungan RSABL.

3. Sistem yang berhasil dirancang memudahkan karyawan dalam permohonan atau pengajuan cuti (paid leave) dan perizinan atau sakit (permit application)

Berdasarkan kesimpulan yang telah dikemukakan, beberapa rekomendasi yang dapat dibuat untuk perbaikan lebih lanjut, antara lain:

1. Aplikasi dapat dibuat berbasis mobile sehingga tidak terlalu menuntut klien untuk menggunakannya.

2. Untuk dapat mengaktualisasikan aplikasi dengan baik, perusahaan dapat melakukan sosialisasi dan persiapan secara matang kepada pekerja sehingga diharapkan dapat menyesuaikan diri dengan baik dengan sistem yang terkomputerisasi.

\section{Referensi}

[1] C. R. Suwu, I. M. Sukarsa and I. P. A. Bayupati, "Pengembangan Sistem Hrm Terintegrasi dengan Pendekatan ERP," MERPATI, ISSN: 2252-3006, vol. 4, no. 3, pp. 256-270, 2016.

[2] C. \&. S. A. Zurnali, "Penerapan Electronic Human Resource Management di Perusahaan," INFOKAM. ISSN: 1829:9458, vol. 17, no. 1, pp. 9 - 19, 2021.

[3] M. N. Almasri, "MANAJEMEN SUMBER DAYA MANUSIA: IMLEMENTASI DALAM PENDIDIKAN ISLAM," Kutubkhanah: Jurnal Penelitian sosial keagamaan, E-ISSN : 2407-1633, vol. 19, no. 2, pp. 134-151, 2016.

[4] P. B. Santoso, M. Asbari and A. Purwanto, "PENGARUH KOMPETENSI, MOTIVASI, KEPEMIMPINAN, KOMITMEN DAN BUDAYA," Jurnal Produktivitas, E-ISSN : 2621-5098, vol. 6, no. 2, pp. 158-166, 2019.

[5] J. Febio and R. Sovia, "MEMBANGUN APLIKASI E-LIBRARY MENGGUNAKAN HTML, PHP SCRIPT, DAN MYSQL DATABASE," Jurnal PROCESSOR, vol. 6, no. 2, pp. 38-54, 2017.

[6] A. Kadir, Pengenalan Sistem Informasi : Edisi Revisi, Yogyakarta: ANDI, 2014.

[7] M. Jonni and S. M. Husain, "PERANCANGAN APLIKASI HUMAN RESOURCE INFORMATION SYSTEM (HRIS) BERBASIS WEBSITE PADA PT. SUPER TATA RAYA STEEL," Jurnal Teknik UMT, vol. 5, no. 2, pp. 102-114, 2016. 
[8] A. Lutfi and M. , "SISTEM INFORMASI HUMAN RESOURCE MANAJEMEN PADA PERUSAHAAN BERBASIS WEB (Studi Kasus: PT. SAMUDRA MAS)," Jurnal Penelitian Dosen FIKOM (UNDA), vol. 8, no. 1, 2018.

[9] M. M. H. Junaedi, S. Susanti and A. Mubarok, "PENERAPAN FRAMEWORK LARAVEL PADA APLIKASI HRIS (HUMAN RESOURCE INFORMATION SYSTEM)," JURNAL RESPONSIF: Riset Sains \& Informatika, E-ISSN : 2685-6964, vol. 2, no. 2, pp. 176-183, 2020.

[10] MZ, M. K. (2016). Pengujian Perangkat Lunak Metode Black Box Berbasis Equivalence Partitions Pada Aplikasi Sistem Informasi Sekolah. Jurnal Mikrotik, 6(3), 30-48. 